\title{
The heat goes on-changes in indices of hot extremes in Poland
}

\author{
Dariusz Graczyk $^{1}$ • Iwona Pińskwar ${ }^{1}$ - Zbigniew W. Kundzewicz ${ }^{1}$ Øystein Hov $^{2}$ • \\ Eirik J. Førland $^{2}$ - Malgorzata Szwed ${ }^{1}$. Adam Choryński ${ }^{1}$
}

Received: 7 April 2015 / Accepted: 20 March 2016/Published online: 7 April 2016

(C) The Author(s) 2016. This article is published with open access at Springerlink.com

\begin{abstract}
On the basis of temperature observations at 60 meteorological stations in Poland, changes in the indices associated with the presence of extremely high air temperatures were examined. Indices associated with heat waves, such as the number of hot days $\left(T_{\max } \geq 30{ }^{\circ} \mathrm{C}\right)$ in the summer months (June, July, August) and beyond the summer months (May, September), the number of extremely hot days $\left(T_{\max } \geq 35^{\circ} \mathrm{C}\right)$, the duration of the longest hot spell in the year, as well as the number of tropical nights $\left(T_{\min } \leq 20{ }^{\circ} \mathrm{C}\right)$ were calculated. Spatial distribution of change rate in days per decade for the studied indices as well as the significance level of the observed trends is illustrated. Also current values of the studied indices (for 1991-2013) are examined and compared with the reference period, 1961-1990. For eight of 11 analysed indexes, increase has been detected in last decades with the help of the Mann-Kendall test at a significance level $\geq 0.05$ or better, for a large group of stations. Statistically significant increases of the number of hot days in summer, the number of tropical nights in a year, and duration of the longest hot spell in summer were found for more than half of the stations. Distinct changes in the duration of heat waves were also noted. In 1961-1990, the longest hot spell lasted for 10 days while in 1991-2013, there were many hot spells longer than that, while the longest hot spell recorded in this period lasted for 17 days. Beyond summer, changes in the number of hot days were smaller. In May, a statistically significant increase was
\end{abstract}

Dariusz Graczyk

darekgraczyk@wp.pl

1 Institute for Agricultural and Forest Environment, Polish Academy of Sciences, Poznań, Poland

2 Norwegian Meteorological Institute, Oslo, Norway recorded for only three stations, while in September the downward trend was dominating and for eight stations it was statistically significant.

\section{Introduction}

Global warming has manifested itself in an increase of mean air temperature at various spatial scales, ranging from local to national, regional, continental, hemispheric, and global (Kundzewicz and Huang 2010, Stanisławska et al. 2013, IPCC 2013). The globally averaged combined land and ocean surface temperature increased by about $0.85[0.65$ to 1.06$]{ }^{\circ} \mathrm{C}$, over the period 1880 to 2012 (IPCC 2013). A similar value of $0.8^{\circ} \mathrm{C}$ was calculated for the area of Poland in the second half of the twentieth century (cf. Fortuniak et al. 2001; Kożuchowski and Żmudzka 2001). Changes of air temperature have considerable impacts, e.g. for agriculture (Graczyk and Kundzewicz 2015). The changes in daily mean air temperature are accompanied by an increase of maximum and minimum values of air temperature for the whole globe estimated in the period $1979-2004$ as about $0.30{ }^{\circ} \mathrm{C} /$ decade for $T_{\min }$ and about $0.29{ }^{\circ} \mathrm{C} /$ decade for $T_{\max }$ (Vose et al. 2005). Similar values (increase of $T_{\min }$ by $0.20-0.30{ }^{\circ} \mathrm{C} /$ decade and of $T_{\max }$ by $0.26^{\circ} \mathrm{C} /$ decade) were found by Kejna et al. (2009) for some regions of Poland in the period 1951-2005. As summarized in IPCC (2013), the number of warm days and nights has increased on the global scale, while the frequency of heat waves has increased in many regions, therein large parts of Europe. Since the end of the nineteenth century, the length of summer heat waves over Western Europe has doubled and the frequency of hot days has almost trebled (Della-Marta et al. 2007). Changes in hot indices have large impacts; hence their shifts raise considerable interest. Increase in the frequency of upcrossing of high temperature thresholds may adversely 
affect the environment, population, and economy. Hence, improving the insight and understanding of such changes is of considerable societal importance. In Poland, since the early 1990s, an increase in the number of hot days as well as ageing of the society (hence increase in its sensitivity to "hot" extremes) have been observed. Poland did not suffer much during the two most severe recent summer heat waves in Europe (in 2003 in Western Europe and in 2010 in Eastern Europe). During both of these summers, when regional and continental temperature records were broken, Poland was beyond the area of highest temperature. The present paper examines changes in indices of hot extremes in Poland in 1951-2013. Hot extremes are measured by such indices as the number of hot and extremely hot days in a year, duration of the longest hot spell in a year, and the number of tropical nights. Spatial distribution of changes in hot extremes in Poland and of amplitude and significance of these changes is presented.

\section{Data}

Although instrumental temperature measurements in Poland, like in other European countries, started around the end of the eighteenth century (Bryś and Bryś 2010), due to historical reasons (armed conflicts, long lasting lack of independent state, and major changes of national boundaries before 1945), records of good quality daily meteorological data in Poland are shorter than in many European countries with more stable history. Polish Meteorological and Hydrological Service (the Institute of Meteorology and Water Management - State Research Institute, Polish acronym: IMGW-PIB) provided the CHASE-PL Project with time series of daily air temperature (mean, maximum, and minimum values) for meteorological stations in Poland. The basic criteria for selection of stations were (i) the length and completeness of the available time series of records and (ii) the spatial distribution of stations with the goal of covering the whole territory of Poland and its climate regions, in a possibly uniform way. Data were used only from stations with no gaps in observation series for the months of May-September, or else from stations with only a few gaps that could be supplemented with data from the archives of synoptic messages and meteorological yearbooks. This procedure of infilling the data was used only for gaps occurring for no more than 10 days in a year. The stations for which gaps extended to longer periods were abandoned even at the expense of worse coverage, e.g. in the north-eastern Poland.

The database consists of air temperature records at $60^{1}$ stations in Poland, therein 53 for the time period 1951-2013.

\footnotetext{
${ }^{1}$ Some of the analysed indices are not present at all examined meteorological stations (e.g. days with temperature $\geq 35^{\circ} \mathrm{C}$ occurred at 55 of 60 available stations).
}

Further eight stations have slightly shorter records, all ending in 2013 and starting, respectively, in 1952 (RzeszówJasionka), 1954 (Nowy Sącz, Przemyśl), 1956 (Terespol), 1957 (Lesko), 1958 (Leszno-Strzyżewice), and 1961 (Krzyż). The spatial distribution of meteorological stations used in the present study is mapped in Fig. 1. Precise information on the location of the mentioned stations can be found in Appendix 1.

Monthly means of maximum and minimum daily temperatures for each of the analysed stations were examined for homogeneity. Four standard tests were used, namely standard normal homogeneity test (SNHT) (Alexandersson 1986), Pettitt's test (Pettitt 1979), Buishand's test (Buishand 1981), and the Von Neumann ratio test (Von Neumann 1941). Used tests and their interpretation were similar to those in Wijingaard et al. (2003). It was acceptable to reject the null hypothesis of homogeneity (at the 0.05 level) only for one of the four used tests.

\section{Methodology}

In the analysis of air temperature extremes, among the most frequently used thresholds are values of 90th and 95th percentile of daily maximum temperature (c.f. Moberg and Jones 2005, Nemec et al. 2013, Alexander et al. 2006, Erlat and Türkeș 2013) or arbitrarily defined values. In this study, definition of air temperature extremes was based upon an arbitrary assumption of thresholds for hot days and extremely hot days at the levels corresponding to the common understanding of these terms in the context of Polish climate: daily maximum temperatures of 30 and $35{ }^{\circ} \mathrm{C}$, respectively. Tropical nights were defined as those with minimum daily temperature in excess of $20^{\circ} \mathrm{C}$. When selecting the indices, the authors considered various air temperature thresholds that had been used in previous climate research in Poland (cf. Koźmiński and Michalska 2011, Kossowska-Cezak and Skrzypczuk 2011, Cebulak and Limanówka 2007, Graczyk and Kundzewicz 2014).

Based on the thresholds defined above, four groups of indices of hot extremes were examined, namely as follows:

- Group of indices representing the number of hot days (with maximum temperature greater than or equal to $30{ }^{\circ} \mathrm{C}$ ). This group of indices can be subdivided seasonally, into the number of hot days in summer (for the whole summer: June to August; and for each of individual summer months: June, July, and August) and in non-summer months (May, September).

- Group of indices describing hot spells (heat waves). One index is the number of days in a year occurring in a hot spell (of minimum three consecutive hot days). 


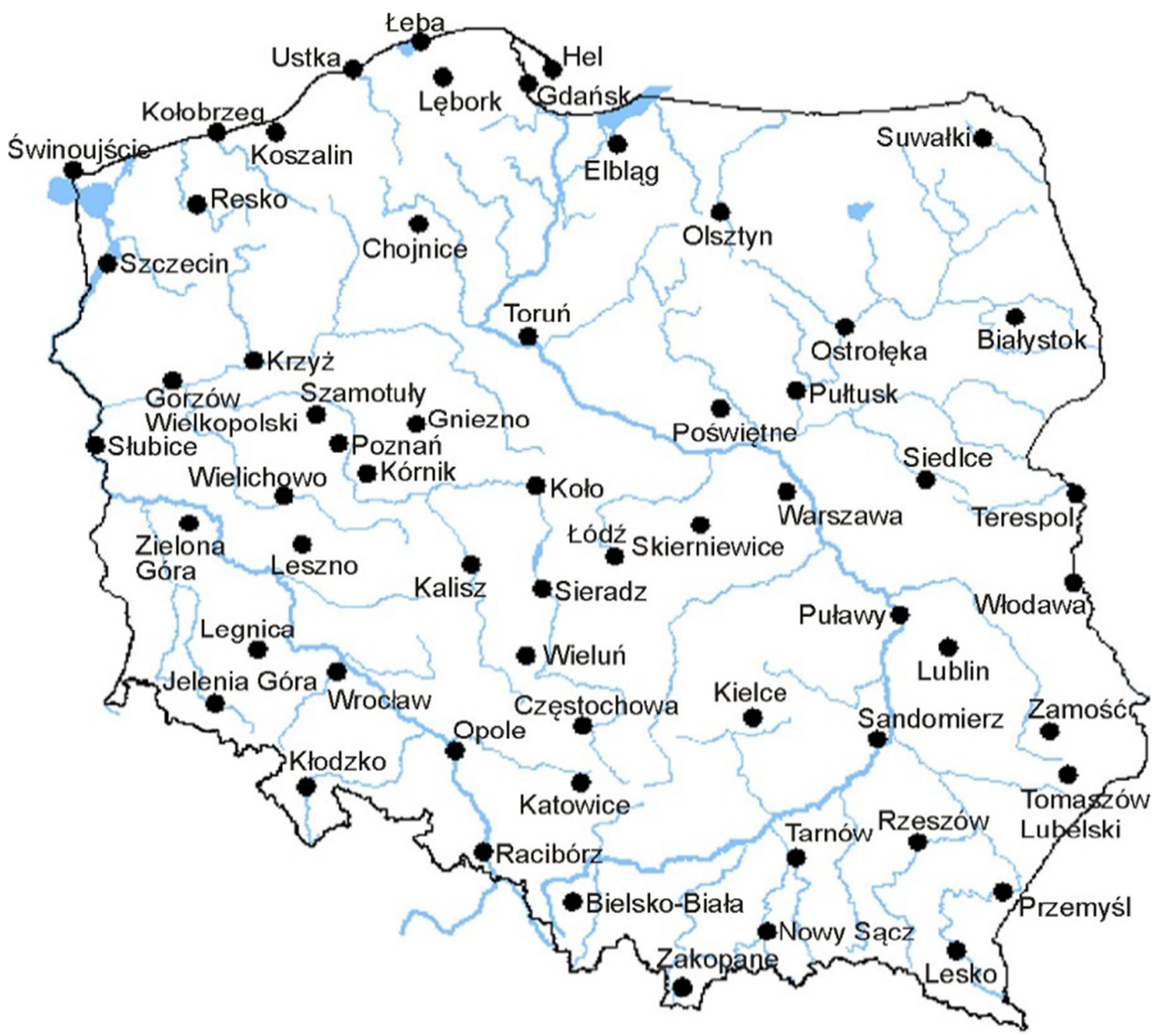

Fig. 1 Location of meteorological stations used in this work

Alternatively, the highest number of consecutive hot days in a year is examined.

- Number of very hot days in a year (with maximum temperature greater than or equal to $35^{\circ} \mathrm{C}$ ).

- Number of tropical nights in a year (with minimum temperature greater than or equal to $20^{\circ} \mathrm{C}$ ).

Time series of annual values of records of the above indices were analysed for each station for the complete time interval of records, in order to detect existing trends with the help of the Hydrospect 2.0 software (Radziejewski and Kundzewicz 2004). The nonparametric Mann-Kendall test examined the rank statistics and was used to determine the significance level. Sign of the statistics of this test represents the direction of the trend; positive (upward) trend is marked on the maps in red and the negative (downward) trend is marked in blue.

The following threshold values of the significance level were used:

- Statistically significant trend at the level of 0.01

- Statistically significant trend at the level of 0.05

- Weaker trend at the significance level of 0.1

- Weak, statistically insignificant trend, at the level of 0.25

- Lack of even a weak tendency, with significance level $>0.25$.

Apart from trend detection in the complete data records, differences between values of indices in two 
Fig. 2 Annual number of hot days $\left(T_{\max } \geq 30{ }^{\circ} \mathrm{C}\right)$ in Poland in 1951-2013 (arithmetical averages calculated from all stations)

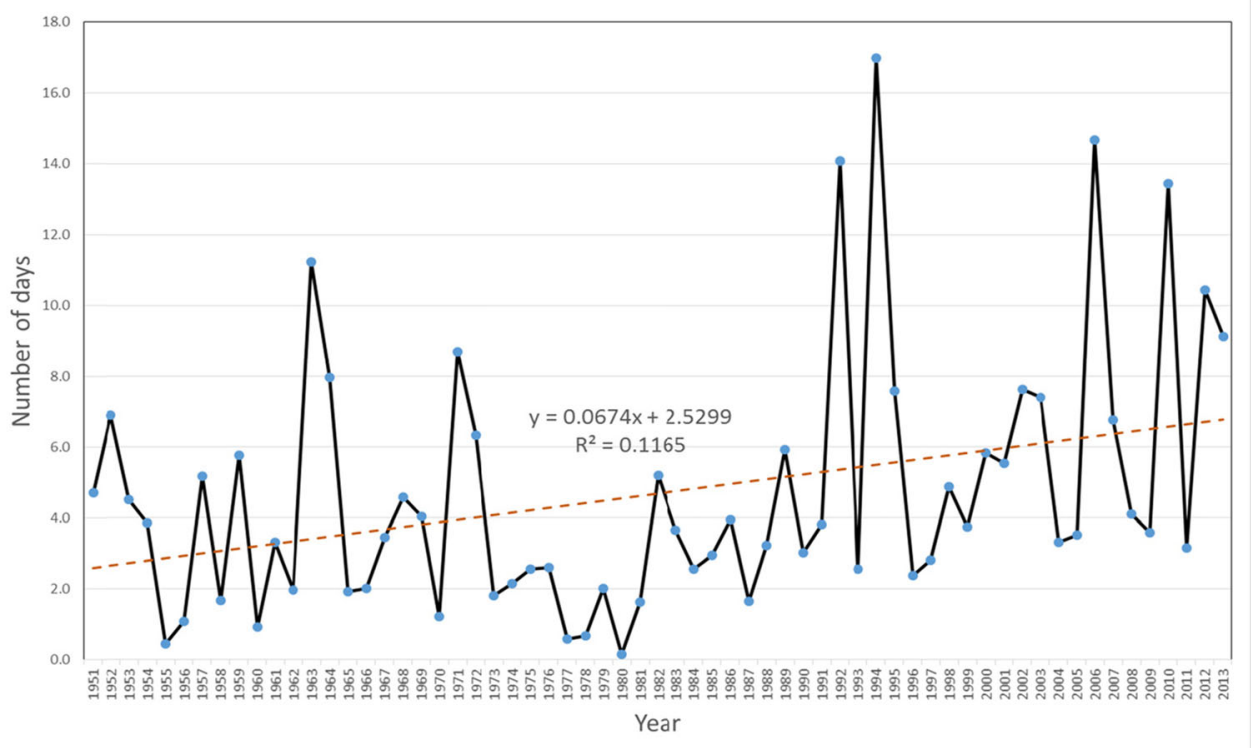

compared intervals, 1961-1990 and 1991-2013, were determined. A 30-year period (such as 1961-1990) has been broadly recognized as a climatological norm and frequently used as a reference period in much of climate change literature. However, since the next 30-year climatological norm, 1991-2020 is now ongoing, there are two possibilities-either to consider a more recent 30- year period 1981-2010 with partial overlap (1981-1990) with the reference period 1961-1990 or to take a shorter interval, 1991-2013, without overlap. The latter option is assumed here. The maps depicting the index values and the differences between the analysed periods were created with the help of ordinary kriging. This interpolation method is known as the best linear

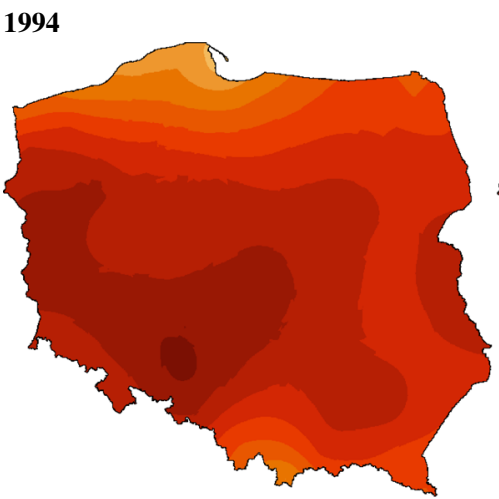

2006

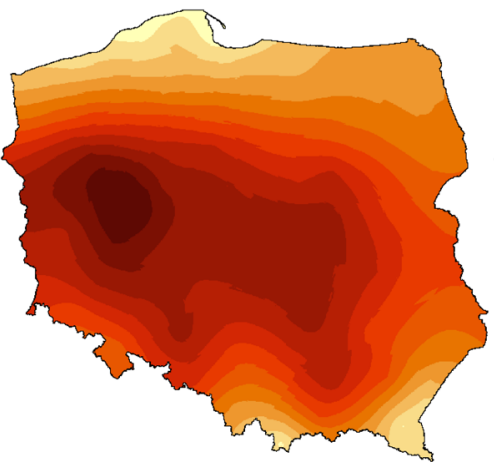

2010

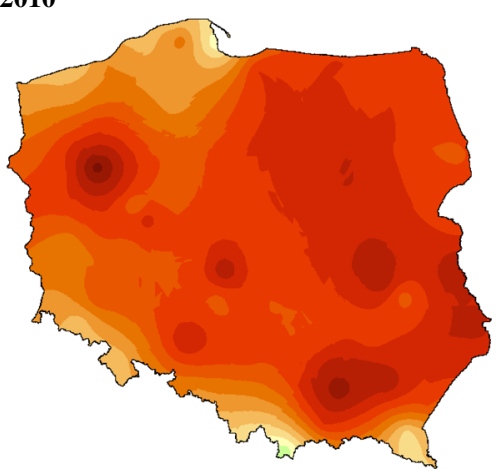

1963

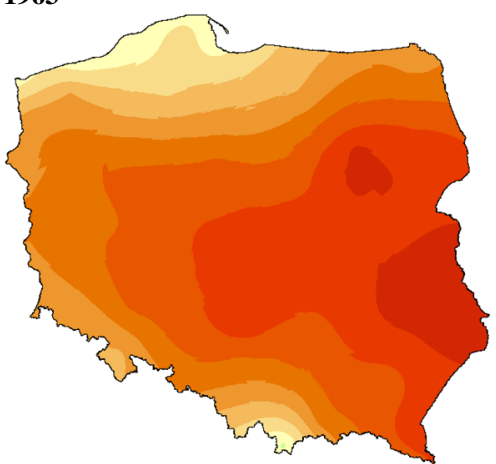

1992

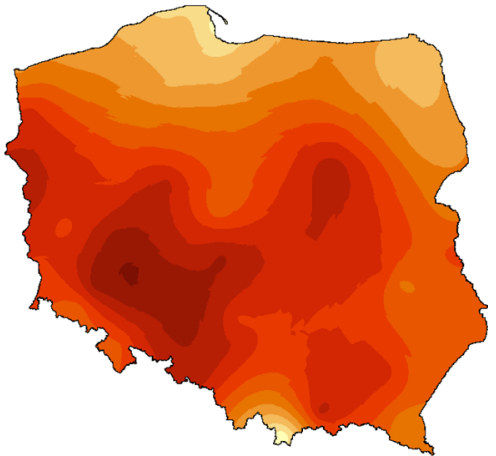

Fig. 3 Spatial distribution of the number of hot days $\left(T_{\max } \geq 30^{\circ} \mathrm{C}\right)$ during 5 years with hottest summers 
Fig. 4 Mean number of days with maximum temperature in excess of $30^{\circ} \mathrm{C}$ in summer, in Poland, a 1991-2013; b changes of the mean number of hot days between 1991-2013 and 19611990 (a)

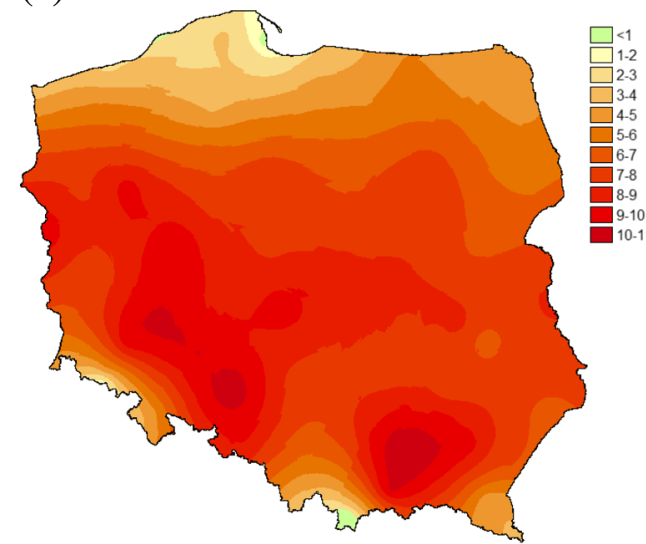

(b)

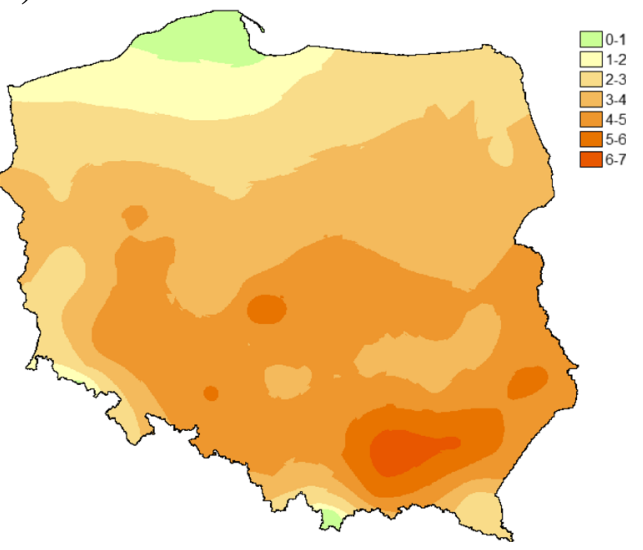

unbiased estimator (B.L.U.E.) because it creates a mean residual or error that is equal to zero and, as well, minimizes the variance of the errors. It is the most common form of kriging interpolation. It calculates a
Fig. 5 Distribution of statistical significance of trend in the number of hot days

$\left(T_{\max } \geq 30^{\circ} \mathrm{C}\right)$ in Poland, for all years of records, starting in 19511961 and ending in 2013; a whole summer; b June; c July; d August; e May; f September. The blue and red colours indicate a downward and an upward trend, respectively (a)

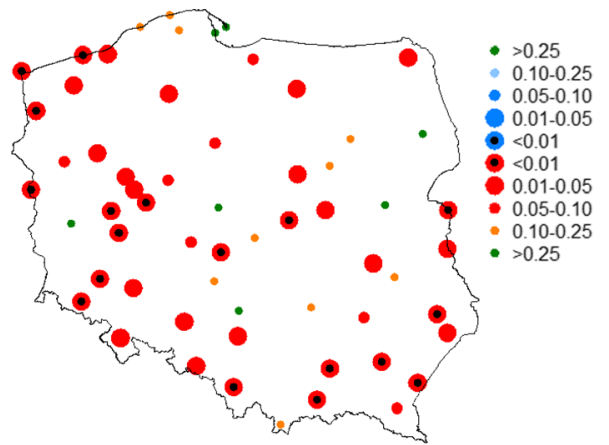

(c)

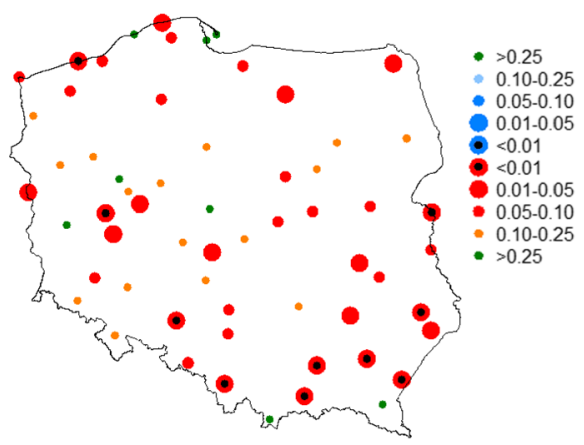

(e)

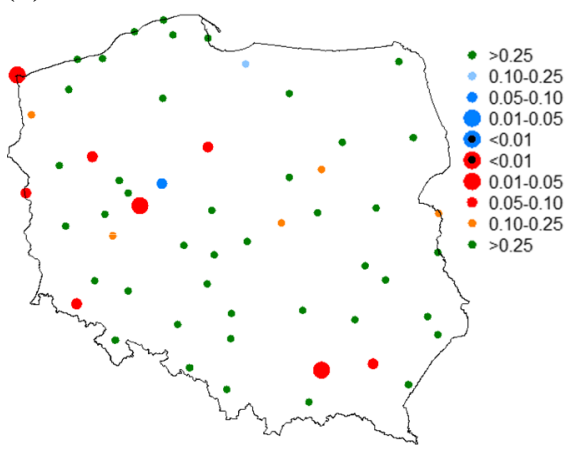

(b)

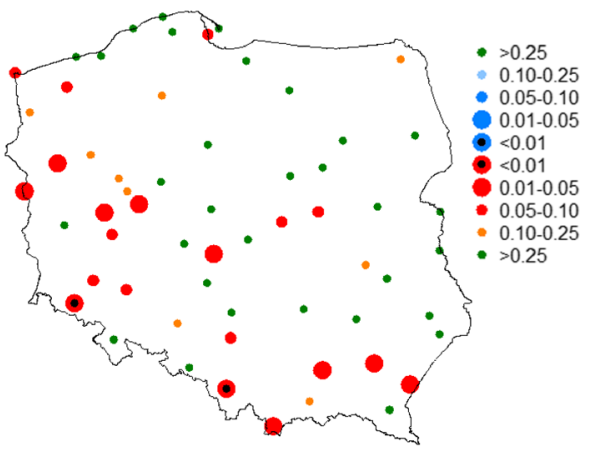

(d)

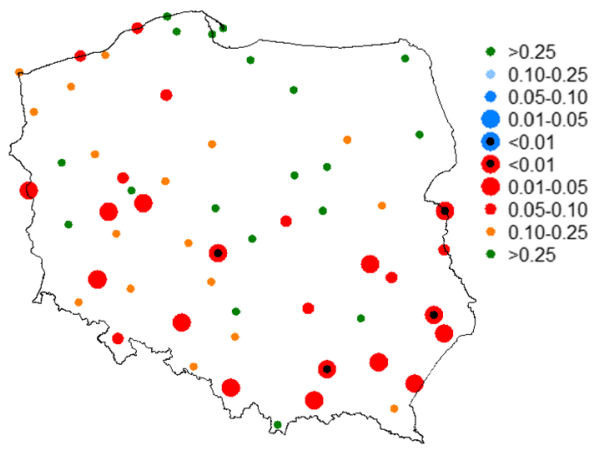

(f)

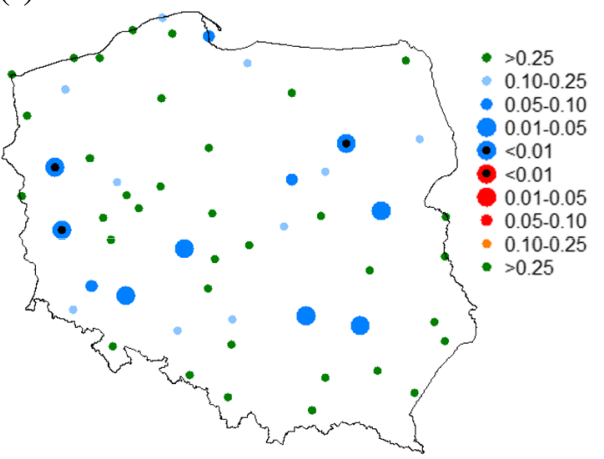


Fig. 6 Rate of change (per decade) in the number of hot days $\left(T_{\max } \geq 30^{\circ} \mathrm{C}\right.$ ) calculated for the linear regression; a for the whole summer and for months b June, c July, d August, e May, and f September. The blue and red colours indicate a downward and an upward trend, respectively (a)

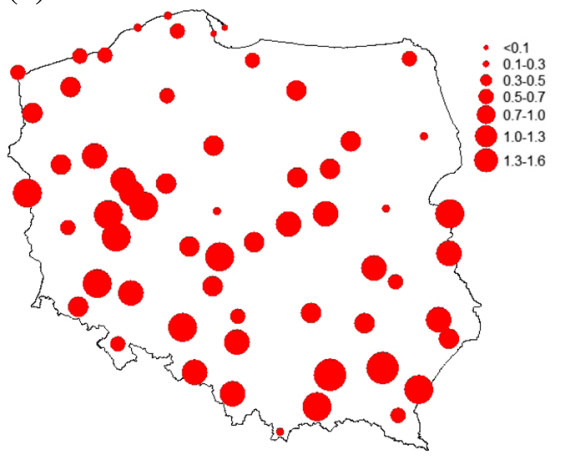

(c)

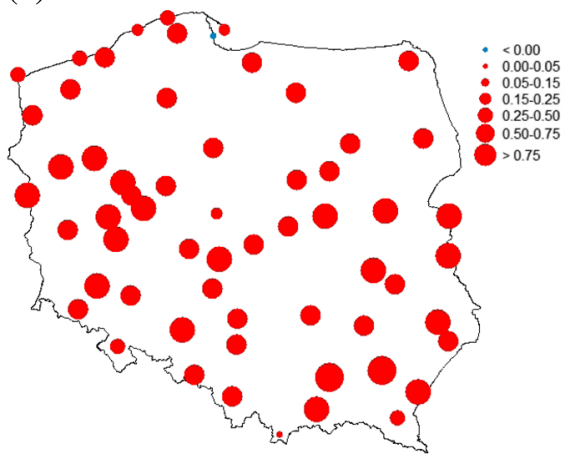

(e)

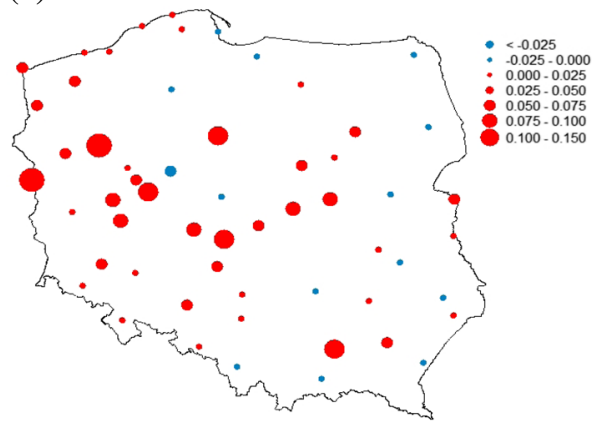

(b)

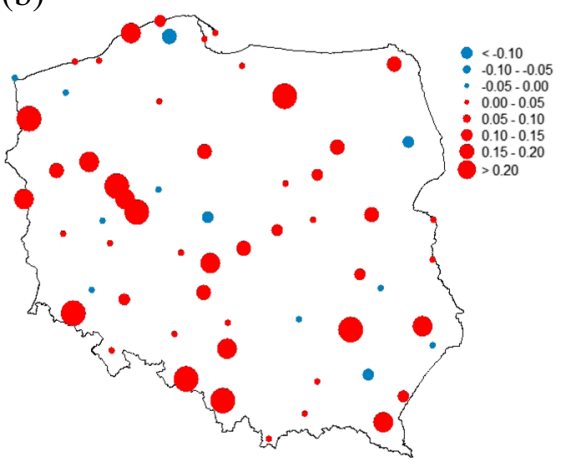

(d)

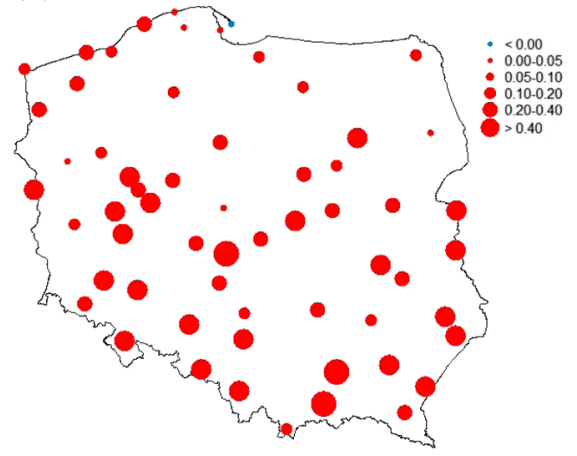

(f)

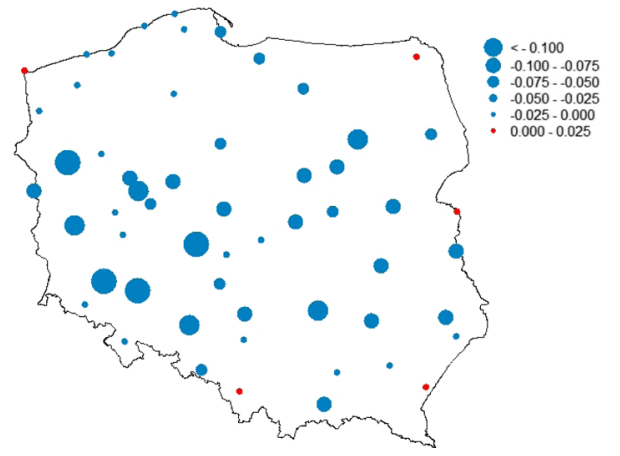

weighted sum of known observations to estimate an unknown value. The observations were selected from a dataset within a user-specified neighbourhood, assuming 5 and 12 as the minimum and the maximum numbers of
Fig. 7 Number of days in a year with maximum temperature greater than or equal to $30^{\circ} \mathrm{C}$ occurring in heat waves a 19912013; b difference between 1991 and 2013 and 1961-1990.

Attention: Figs. 7a and $\mathrm{b}$ have different colour scales (a)

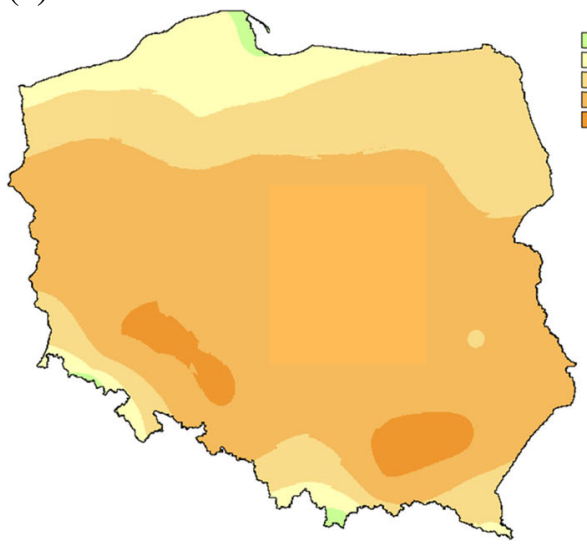

(b)

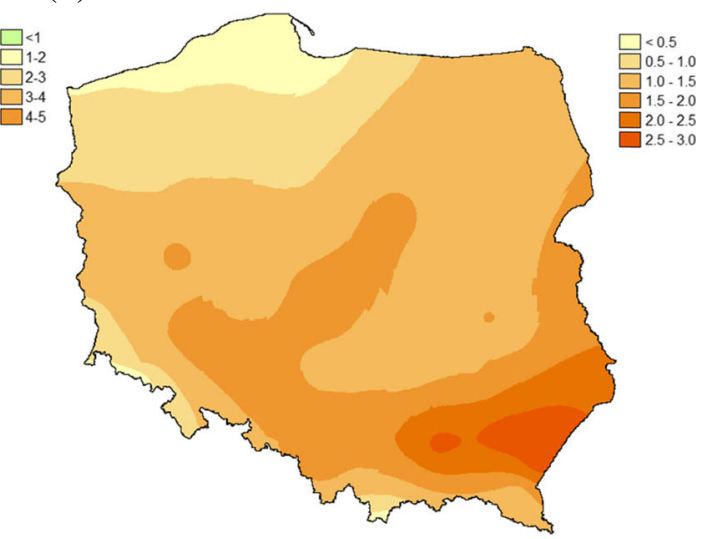


Fig. 8 Spatial distribution of characteristics relevant to the number of days in a year with maximum temperature greater than or equal to $30^{\circ} \mathrm{C}$, occurring in a hot spell (of minimum three consecutive hot days). a

Statistical significance of trend. $\mathbf{b}$ Rate of change (in days per decade) (a)

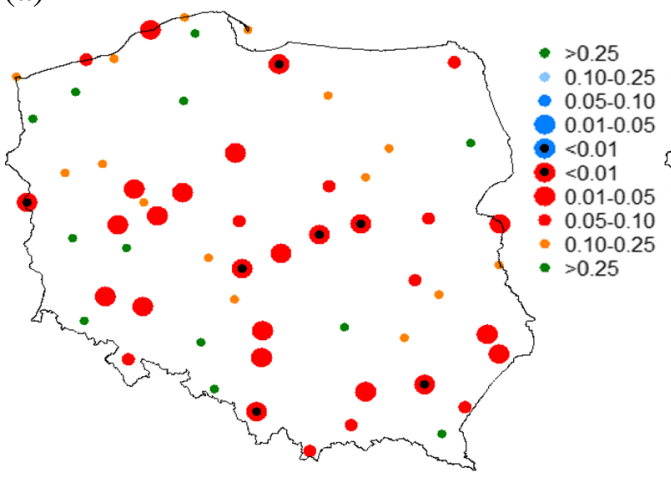

(b)

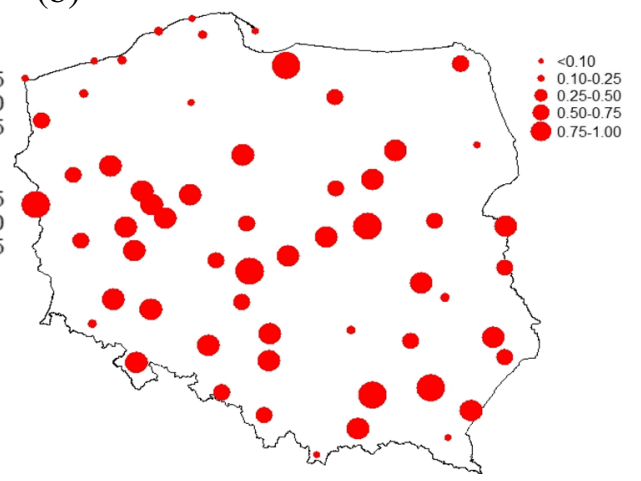

sample points, respectively. Even if ordinary kriging may underestimate high values and overestimate low values, if the overall distribution of temperature is of interest, kriging is an optimal predictor.

Further, heat waves in particularly hot summers (1963, 1992, 1994, 2006, 2010) are reviewed in more detail.

\section{Results}

Figure 2 illustrates the increasing trend in the spatial mean value of the number of hot days in a year (at all stations and for all intervals for which uninterrupted data sets are available, i.e. 60 stations in 1961-2013, 59 stations in 1958-1960, 58 stations in 1956-1957, 55 stations in 1954-1955, 54 stations in 1952-1953, and 53 stations in 1951). Five of the 6 years with the highest number of hot days appeared after 1990. A period of about 20 years (1970s and 1980s) with less frequent occurrence of hot days is also clearly visible. The values of significance levels of the Mann-Kendall test were, respectively, 0.0062 for all stations and 0.0070 for the stations with the complete observation period, 1951-2013. Hence, for both cases, the changes were statistically significant at $\alpha=0.01$ level.

Figure 3 illustrates the spatial distribution of the number of hot days (with $\operatorname{Tmax} \geq 30{ }^{\circ} \mathrm{C}$ ) in 5 years with hottest summers. The hottest summer in the whole country scale occurred in 1994, when almost in the whole country more than 16 hot days were recorded, while in the south-western Poland the number of hot days exceeded 20. The year 2006 gave the way slightly, as more than 16 hot days were observed on a smaller area, but in a part of the Wielkopolska region even 26 hot days were observed. More than 20 hot days were also observed in 1992, on a small area though. During the heat waves of 2010 and 1963, the highest number of hot days was observed in the east of Poland, but then the number of days did not exceed 18. Due to a lack of data, the hot summer of 2015 (with hottest August on record for much of Poland) could not be included.

\subsection{Changes in frequency of hot days}

Figure 4a maps the long-term mean of the number of hot days $\left(T_{\max } \geq 30{ }^{\circ} \mathrm{C}\right)$ in summer (JJA) for the time period 1991-2013. The range extends from less than one to more than 10 days per year. The lowest numbers were observed in Zakopane (at the foothills of the high Tatra Mountains) and in the Baltic Sea coast, while the highest numbers were observed in the south and in the west of the country.
Fig. 9 Spatial distribution of characteristics relevant to the length of the longest hot spell in a year. a Statistical significance of trend. b Rate of change (in days per decade). The blue and red colours indicate a downward and an upward trend, respectively (a)

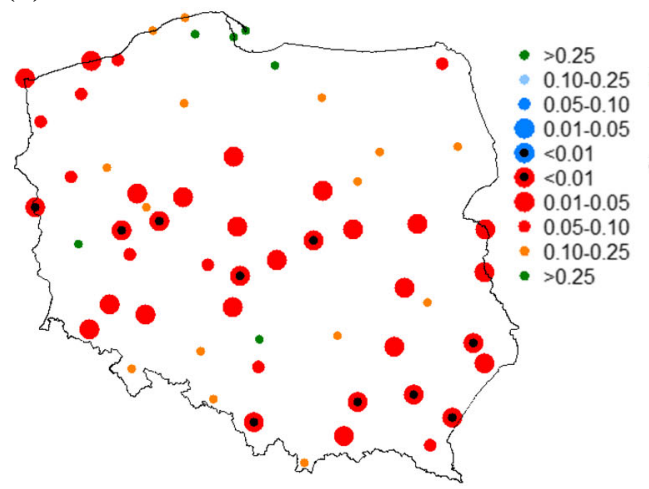

(b)

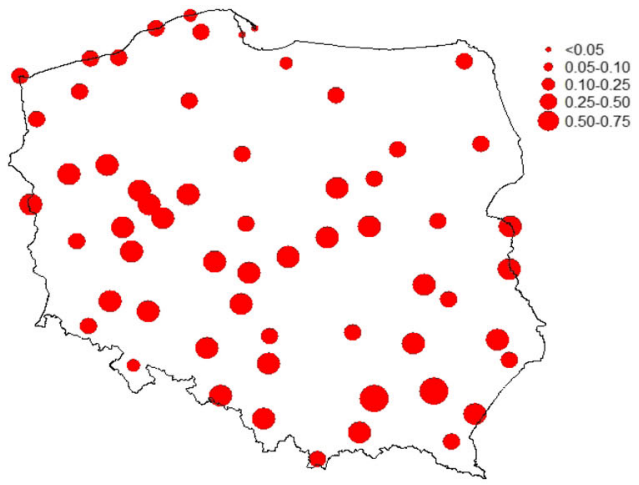


Fig. 10 The frequency of hot spells within the intervals of their duration

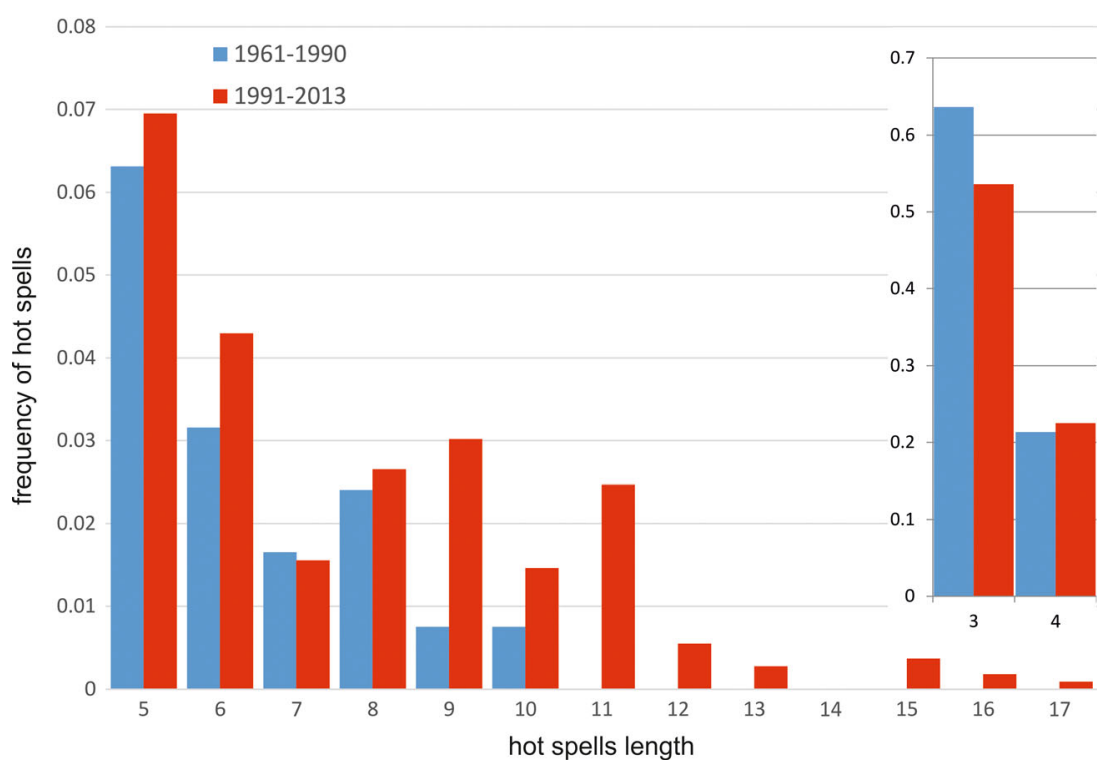

Figure $4 \mathrm{~b}$ illustrates the difference between the number of hot days $\left(T_{\max } \geq 30{ }^{\circ} \mathrm{C}\right)$ in summer, in 19912013 and in 1961-1990. After 1990, a large increase of the number of hot days was noted. The frequency has doubled for almost half of the stations, including nearly every station in the southern and eastern parts of the country.

Figure 5a illustrates the spatial distribution of statistical significance of trend (Mann-Kendall test) for the whole summer. Most stations (36 of 60) show a statistically significant upward trend, indicating increase of the number of hot days. There are no stations with decreasing trends. When analysing particular months, 20 stations showed statistically significant increases in July (less so in August and June). The number of hot days in May and September is low and does not exceed 1 day in a year, on average. In May (Fig. 5e), there are increases at 44 stations and decreasing tendency at some stations, but there are statistically significant increases only in three cases. In contrast, in September (Fig. 5f), there are 39 decreases, therein eight are statistically significant.

For some indices, a statistically significant upward trend comes together with a large rate of change of the value of indices per decade (Fig. 6). For 40 stations, the number of hot days in summer (Fig. 6a) increased in the analysed period at a rate above 0.5 day per decade and for 12 stations at a rate exceeding 1 day per decade. For the summer months (Fig. 6b-d), changes were less visible for June, exceeding the value of 0.2 day per decade for only eight stations. The number of hot days in July increased much faster, exceeding 0.5 day per decade for 20 stations and 0.4 day per decade for another 17 stations. The number of hot days in August grew fast for most stations (31) with a rate of 0.1-0.3 day per decade. In the non-summer months
Fig. 11 Mean number of extremely hot days $\left(T_{\max } \geq 35^{\circ} \mathrm{C}\right)$ in a year, in Poland, a 1991-2013. b difference between 1991 and 2013 and 1961-1990 (a)

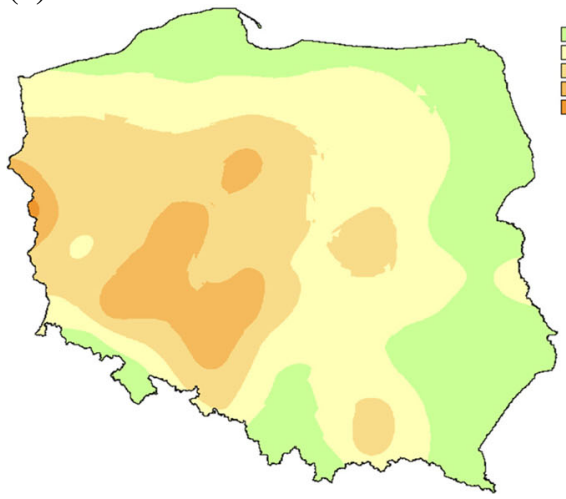

(b)

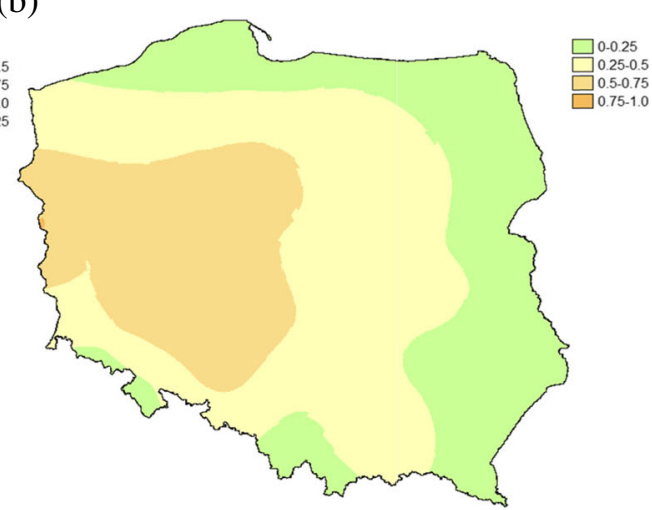


Fig. 12 Spatial distribution of characteristics relevant to the number of extremely hot days $\left(T_{\max } \geq 35^{\circ} \mathrm{C}\right)$ in a year. a Statistical significance of trend. $\mathbf{b}$ Rate of change (in days per decade). The blue and red colours indicate a downward and an upward trend, respectively (a)

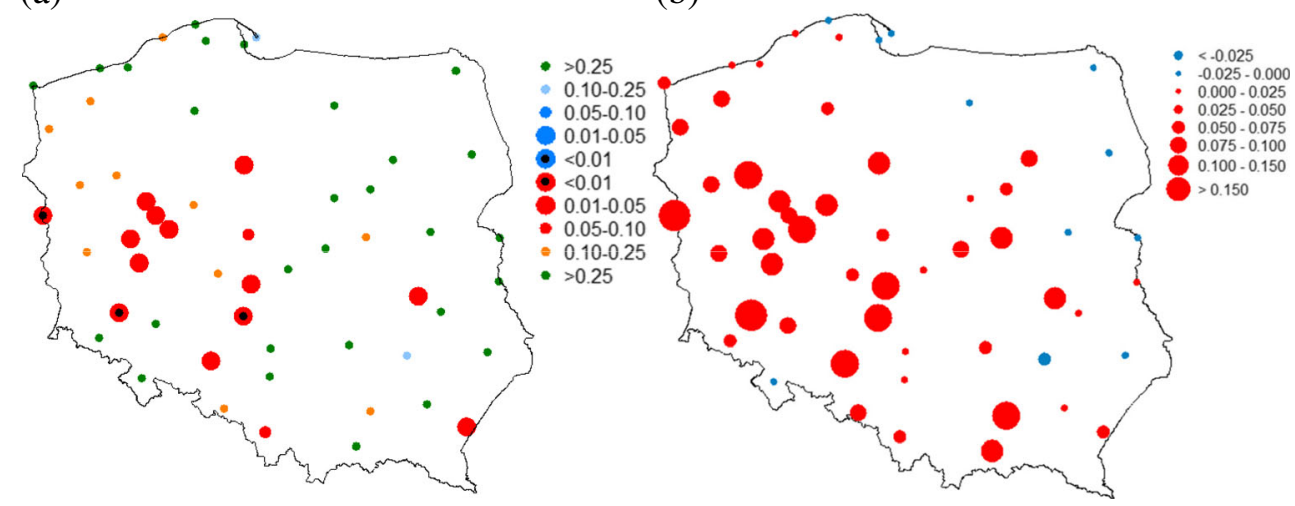

(Fig. 6e-f), the rate of the upward trend for May and the downward trend for September exceeded 0.1 day per decade only for a few stations.

\subsection{Heat wave indices}

The mean number of hot days (with maximum temperature greater than or equal to $30^{\circ} \mathrm{C}$ ) occurring in a heat wave, also called hot spell (of minimum three consecutive hot days), in a year from the interval 1991-2013 range from 0.5 per year at the Baltic coast and in Zakopane to more than five in the south and west (Fig. 7a). A mean value below 3 days can be interpreted that the frequency of heat waves is, on average, less than once a year. The difference between 1991-2013 and 1961-1990 is positive at all stations, mostly exceeding 1 day per year and for half of stations, reaching 2 days per year or more (Fig. $7 b$ ). For stations in the south and the east, there were cases of trebling the number of consecutive hot days. Before 1990, at stations located at the Baltic coast, a series of three consecutive hot days had not occurred.
The statistical significance of trend (Mann-Kendall test) of the number of hot days occurring in a hot spell (of minimum three consecutive hot days) for the whole record shows upward trends for 56 of 57 stations. In 22 cases, this trend is statistically significant at least at the 0.05 level (Fig. 8a). The rate of change of this index, measured by linear trend exceeded 0.5 day per decade for almost half of the analysed stations (29) including stations for which Mann-Kendall test indicate statistical significance of changes (Fig. 8b). For further 15 locations, the change was in the range of $0.25-0.5$ per decade.

For a large group of stations, a statistically significant increasing trend was detected in the duration of the longest interval of consecutive hot days in a year (Fig. 9a). For 30 stations, the increasing trend was statistically significant at the level of $\alpha \leq 0.05$, including 10 stations with $\alpha \leq 0.01$. For almost $2 / 3$ of stations, the longest period of hot days in a year increased at a rate higher than 0.25 day per decade (Fig. 9b).

Figure 10 illustrates the frequency of heat waves of varying lengths for both analysed multi-year intervals. When comparing histograms of distribution of duration
Fig. 13 Mean number of tropical nights $\left(T_{\min } \geq 20^{\circ} \mathrm{C}\right)$ in a year, in Poland, a 1991-2013; b difference between 1991 and 2013 and 1961-1990 (a)

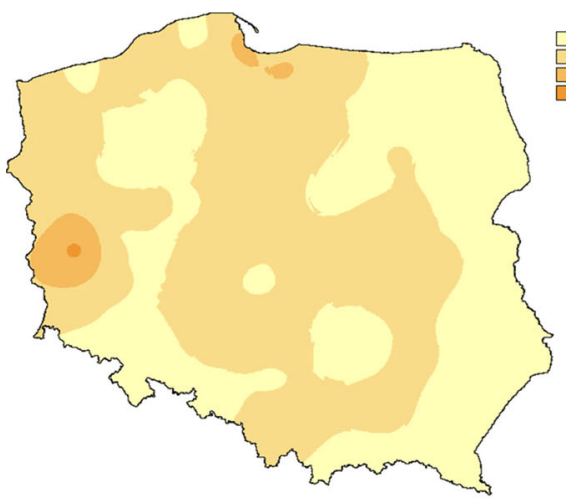

(b)

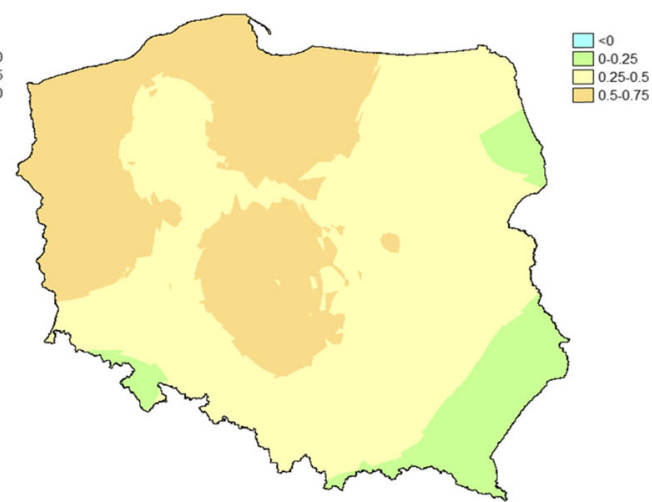


Fig. 14 Spatial distribution of characteristics relevant to the number of tropical nights $\left(T_{\min } \geq 20^{\circ} \mathrm{C}\right)$ in a year, in Poland. a Statistical significance of trend. b Rate of change (in days per decade). The blue and red colours indicate a downward and an upward trend, respectively (a)

(b)

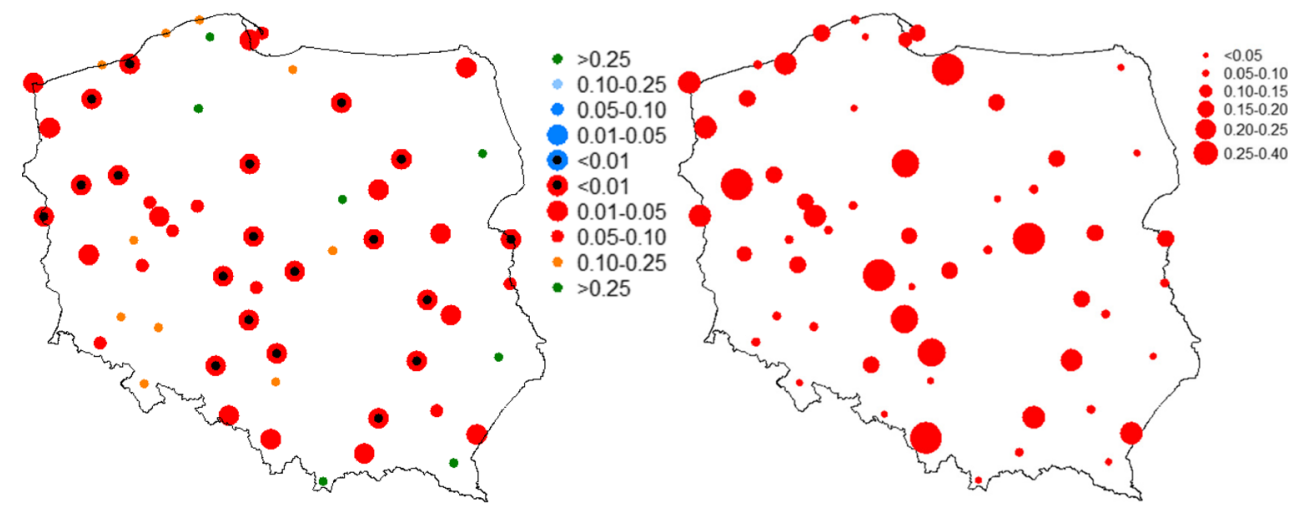

of heat waves in 1991-2013 vs 1961-1990, one can see that the frequency has shifted towards the longer durations. The contributions of hot spells of duration of 3 days (as well as of duration of 7 days) have decreased, while there is a higher frequency for all other durations. Despite the smaller number of years in the period 1991-2013, the absolute number of heat waves is greater for all classes of heat wave duration. In the years 1961-1990, the duration of the longest heat wave reached 10 days, while after 1990 the longest hot spell lasted for 17 days.

\subsection{Changes in the number of extremely hot days}

The number of extremely hot days (with maximum temperature greater than or equal to $35{ }^{\circ} \mathrm{C}$ ) refers to a rarely occurring phenomenon. For 13 of the analysed stations, there is, on average, less than one occurrence per decade, while for 21 stations, such a temperature threshold is exceeded more than once in 2 years and for one station more than once per year (Fig. 11a).

The value of this index has increased between 19611990 and 1991-2013 in the whole country. Even if the absolute increase (in days) is not high, the frequency has considerably increased (Fig. 11b).

Analysis of statistical significance of the trend (Mann-Kendall test) for the whole record shows upward trends for 43 stations; therein, for 13 stations located mainly in the south-western part of the country, trends are statistically significant at the 0.05 level (Fig. 12a). Due to the rare occurrence of extremely hot days, even for stations where the change was statistically significant, the rate of decadal changes in the value of the index (Fig. 12b) reached 0.1-0.2 per decade.

Table 1 Synthesis of results

\begin{tabular}{|c|c|c|c|c|c|c|}
\hline \multirow[t]{2}{*}{ Index } & \multicolumn{3}{|c|}{ Number of stations with increase } & \multicolumn{3}{|c|}{ Number of stations with decrease } \\
\hline & $\mathrm{SL} \leq 0.01$ & $0.01<\mathrm{SL} \leq 0.05$ & $0.05<\mathrm{SL} \leq 0.1$ & $\mathrm{SL} \leq 0.01$ & $0.01<\mathrm{SL} \leq 0.05$ & $0.05<\mathrm{SL} \leq 0.1$ \\
\hline Number of hot days in Summer & 18 & 18 & 7 & 0 & 0 & 0 \\
\hline Number of hot days in June & 2 & 9 & 9 & 0 & 0 & 0 \\
\hline Number of hot days in July & 10 & 10 & 16 & 0 & 0 & 0 \\
\hline Number of hot days in August & 4 & 11 & 9 & 0 & 0 & 0 \\
\hline Number of hot days beyond Summer & 0 & 1 & 2 & 0 & 0 & 7 \\
\hline Number of hot days in May & 0 & 3 & 5 & 0 & 0 & 1 \\
\hline Number of hot days in September & 0 & 0 & 0 & 3 & 5 & 3 \\
\hline Number of days in hot spells & 7 & 15 & 10 & 0 & 0 & 0 \\
\hline Longest hot spell & 10 & 20 & 9 & 0 & 0 & 0 \\
\hline Number of extremely hot days & 3 & 10 & 2 & 0 & 0 & 0 \\
\hline Tropical nights & 19 & 13 & 9 & 0 & 0 & 0 \\
\hline
\end{tabular}

Italic numbers indicate statistical significance of $\alpha \leq 0.05$

$S L$ significance level of Mann-Kendall test 


\subsection{Tropical nights}

The number of tropical nights has also increased. However, occurrence of a tropical night is still a relatively rare phenomenon (Fig. 13a). At stations in the east, tropical nights do not occur more frequently than once per decade. Most frequently, tropical nights occur in Zielona Góra (on average 2.7 nights per year).

For all stations, the value of the index increased after 1990 (i. e. when compared between 1961 and 1990 and 19912013). The highest increase was observed at stations where the number of tropical nights is the highest (Fig. 13b).

For 55 out of 56 stations, the Mann-Kendall test indicated existence of an upward trend, while for 32 stations the trend was statistically significant at least at the 0.05 level (Fig. 14a). Despite the existence of a statistically significant upward trend for more than half of the stations, due to rare occurrence of tropical nights, for no station the increase exceeds 0.4 nights per decade and only for 10 stations it is greater than the 0.2 nights per decade (Fig. 14b).

\section{Synthesis}

Table 1 presents the synthesis of results, illustrating the number of stations with changes at significance levels of 0.01 , 0.05 , and 0.1 . Most persuading results have been observed for the number of hot days in summer (36 increases at a significance level of $\alpha \leq 0.05$ ), for the number of tropical nights (32 increases at a significance level of $\alpha \leq 0.05$ ), and for the longest hot spell (30 increases at a significance level of $\alpha \leq 0.05)$. Statistically significant decreasing trends were observed only for the number of hot days in September (eight stations).

\section{Discussions and conclusions}

Analysis of changes in occurrence of hot air temperature extremes in Poland showed visible changes in the frequency of their occurrence in recent decades for eight of 11 examined indices presented in Table 1.

For a large number of stations, the observed changes in the number of hot days (with $T_{\max } \geq 30{ }^{\circ} \mathrm{C}$ ) were confirmed by Mann-Kendall test, most frequently in relation to annual or to seasonal (summer) data, and less frequently for individual months.

Relatively large changes were found for the rare extremes that occur with frequency of once per year or less, such as the number of tropical nights (with $T_{\min } \geq 20^{\circ} \mathrm{C}$ ) and the number of extremely hot days (with $T_{\max } \geq 35{ }^{\circ} \mathrm{C}$ ). For numerous stations over the whole area of research, Mann-Kendall test confirms statistically significant changes in the number of tropical nights between the periods 1961-1990 and 19912013. Statistically significant increasing trend of the number of extremely hot days was confirmed only for about a quarter of stations located mostly in south-west of Poland.

There are still no clear changes in occurrence of hot days in non-summer months. In May, one can spot an increasing track (but statistical significance holds for a single station only), but in September, a statistically significant decreasing trend is detected for eight stations.

Presented results are in line with previously published research indicating an increase of "hot" extremes for the whole Europe (Yan et al. 2002), as well as for regions and particular countries (Croitoru and Piticar 2012, El Kenawy et al. 2011, Hundecha and Bardossy 2005). These studies dealt with time series of records commencing in the mid-twentieth century (Klein Tank and Konnen 2003, Nemec et al. 2013) and earlier (Moberg and Jones 2005). Some records began in the nineteenth century (Della-Marta 2007, Yan et al. 2002).

In comparison to previous works for the area of Poland, embracing the periods of 1986-2009 (Koźmiński and Michalska 2011) and 1951-2006 (Wibig 2012), this work offers stronger findings. Observed changes have been statistically significant for a larger number of stations and in regions where changes have not been statistically significant for shorter series that ended earlier. Stronger trends for change detection in time series of "hot" extremes in Poland that ended in recent years are caused by more frequent occurrences of very hot summers in last decades that are also described in other studies at the European and regional scale (Twardosz and Kossowska-Cezak 2013, 2015; Shevchenko et al. 2014).

A clear increase of part of indices that has not always been rated as statistically significant by tests might be a consequence of the adopted reference period (WMO standard normal) when several years had lower maximum temperatures in summer (cf. Fig. 2). This is not a local phenomenon, because it has also occurred in the Mediterranean region and Turkey (Xoplaki et al. 2003, Erlat and Türkeș 2013).

Detection of no statistically significant increasing trend in some indices as well as detection of a significant decreasing trend in the number of days with $T_{\max } \geq 30^{\circ} \mathrm{C}$ in September in part of the stations has been also reported in Austria (Nemec et al. 2013) and in Germany (Hundecha and Bardossy 2005).

Acknowledgments The reported research has been carried out within the CHASE-PL (Climate change impact assessment for selected sectors in Poland) project of the Polish-Norwegian Research Programme in the frame of Project Contract No. Pol-Nor/200799/90/2014. Observation data used in this work were provided by the Institute of Meteorology and Water Management - State Research Institute (IMGW-PIB). Useful constructive remarks of two anonymous referees are also gratefully acknowledged. 


\section{Appendix 1}

Table 2 List of meteorological stations used in this work

\begin{tabular}{|c|c|c|c|c|c|c|c|}
\hline Station & Latitude & Longitude & $\begin{array}{l}\text { Elevation } \\
\text { [m. a.s.1.] }\end{array}$ & Station & Latitude & Longitude & $\begin{array}{l}\text { Elevation } \\
\text { [m. a.s.l.] }\end{array}$ \\
\hline Białystok & $53^{\circ} 06^{\prime}$ & $23^{\circ} 10^{\prime}$ & 148 & Poświętne & $52^{\circ} 38^{\prime}$ & $20^{\circ} 23^{\prime}$ & 101 \\
\hline $\begin{array}{l}\text { Bielsko-Biała- } \\
\text { Aleksandrowice }\end{array}$ & $49^{\circ} 48^{\prime}$ & $19^{\circ} 00^{\prime}$ & 398 & Poznań & $52^{\circ} 25^{\prime}$ & $16^{\circ} 50^{\prime}$ & 86 \\
\hline Chojnice & $53^{\circ} 42^{\prime}$ & $17^{\circ} 33^{\prime}$ & 172 & Przemyśl & $49^{\circ} 48^{\prime}$ & $22^{\circ} 46^{\prime}$ & 279 \\
\hline Częstochowa & $50^{\circ} 49^{\prime}$ & $19^{\circ} 06^{\prime}$ & 295 & Puławy & $51^{\circ} 25^{\prime}$ & $21^{\circ} 58^{\prime}$ & 142 \\
\hline Elblagg-Milejewo & $54^{\circ} 10^{\prime}$ & $19^{\circ} 26^{\prime}$ & 38 & Pułtusk & $52^{\circ} 44^{\prime}$ & $21^{\circ} 06^{\prime}$ & 95 \\
\hline Gdynia & $54^{\circ} 31^{\prime}$ & $18^{\circ} 34^{\prime}$ & 2 & Racibórz-Studzienna & $50^{\circ} 05^{\prime}$ & $18^{\circ} 13^{\prime}$ & 190 \\
\hline Gniezno & $52^{\circ} 33^{\prime}$ & $17^{\circ} 34^{\prime}$ & 124 & Resko & $53^{\circ} 46^{\prime}$ & $15^{\circ} 25^{\prime}$ & 51 \\
\hline Gorzów Wielkopolski & $52^{\circ} 45^{\prime}$ & $15^{\circ} 17^{\prime}$ & 72 & Rzeszów-Jasionka & $50^{\circ} 06^{\prime}$ & $22^{\circ} 03^{\prime}$ & 200 \\
\hline Hel & $54^{\circ} 36^{\prime}$ & $18^{\circ} 49^{\prime}$ & 1 & Sandomierz & $50^{\circ} 42^{\prime}$ & $21^{\circ} 43^{\prime}$ & 217 \\
\hline Jelenia Góra & $50^{\circ} 54^{\prime}$ & $15^{\circ} 48^{\prime}$ & 342 & Siedlce & $52^{\circ} 11^{\prime}$ & $22^{\circ} 16^{\prime}$ & 146 \\
\hline Kalisz & $51^{\circ} 44^{\prime}$ & $18^{\circ} 05^{\prime}$ & 140 & Sieradz & $51^{\circ} 36^{\prime}$ & $18^{\circ} 44^{\prime}$ & 137 \\
\hline Katowice & $50^{\circ} 29^{\prime}$ & $19^{\circ} 05^{\prime}$ & 317 & Skierniewice & $51^{\circ} 58^{\prime}$ & $20^{\circ} 10^{\prime}$ & 129 \\
\hline Kielce-Suków & $50^{\circ} 51^{\prime}$ & $20^{\circ} 37^{\prime}$ & 268 & Stubice & $52^{\circ} 21^{\prime}$ & $14^{\circ} 36^{\prime}$ & 21 \\
\hline Kłodzko & $50^{\circ} 26^{\prime}$ & $16^{\circ} 39^{\prime}$ & 316 & Suwałki & $54^{\circ} 08^{\prime}$ & $22^{\circ} 57^{\prime}$ & 184 \\
\hline Koło & $52^{\circ} 12^{\prime}$ & $18^{\circ} 40^{\prime}$ & 116 & $\begin{array}{l}\text { Szamotuły- } \\
\text { Baborówko }\end{array}$ & $52^{\circ} 35^{\prime}$ & $16^{\circ} 38^{\prime}$ & 75 \\
\hline Kołobrzeg & $54^{\circ} 11^{\prime}$ & $15^{\circ} 35^{\prime}$ & 3 & Szczecin-Dąbie & $53^{\circ} 24^{\prime}$ & $14^{\circ} 37^{\prime}$ & 1 \\
\hline Koszalin & $54^{\circ} 12^{\prime}$ & $16^{\circ} 09^{\prime}$ & 33 & Świnoujście & $53^{\circ} 55^{\prime}$ & $14^{\circ} 14^{\prime}$ & 6 \\
\hline Kórnik & $52^{\circ} 15^{\prime}$ & $17^{\circ} 06^{\prime}$ & 77 & Tarnów & $50^{\circ} 02^{\prime}$ & $20^{\circ} 59^{\prime}$ & 209 \\
\hline Krzyż & $52^{\circ} 53^{\prime}$ & $16^{\circ} 01^{\prime}$ & 35 & Terespol & $52^{\circ} 04^{\prime}$ & $23^{\circ} 37^{\prime}$ & 133 \\
\hline Legnica & $51^{\circ} 13^{\prime}$ & $16^{\circ} 10^{\prime}$ & 122 & Tomaszów Lubelski & $50^{\circ} 27^{\prime}$ & $23^{\circ} 25^{\prime}$ & 273 \\
\hline Lesko & $49^{\circ} 28^{\prime}$ & $22^{\circ} 20^{\prime}$ & 386 & Toruń & $53^{\circ} 03^{\prime}$ & $18^{\circ} 35^{\prime}$ & 69 \\
\hline Leszno-Strzyżewice & $51^{\circ} 50^{\prime}$ & $16^{\circ} 32^{\prime}$ & 91 & Ustka & $54^{\circ} 35^{\prime}$ & $16^{\circ} 52^{\prime}$ & 6 \\
\hline Lębork & $54^{\circ} 33^{\prime}$ & $17^{\circ} 45^{\prime}$ & 17 & Warszawa-Okęcie & $52^{\circ} 09^{\prime}$ & $20^{\circ} 59^{\prime}$ & 106 \\
\hline Lublin-Radawiec & $51^{\circ} 13^{\prime}$ & $22^{\circ} 24^{\prime}$ & 238 & Wielichowo & $52^{\circ} 07^{\prime}$ & $16^{\circ} 21^{\prime}$ & 65 \\
\hline Łeba & $54^{\circ} 45^{\prime}$ & $17^{\circ} 32^{\prime}$ & 2 & Wieluń & $51^{\circ} 13^{\prime}$ & $18^{\circ} 35^{\prime}$ & 195 \\
\hline Łódź-Lublinek & $51^{\circ} 44^{\prime}$ & $18^{\circ} 24^{\prime}$ & 187 & Włodawa & $51^{\circ} 33^{\prime}$ & $23^{\circ} 33^{\prime}$ & 175 \\
\hline Nowy Sącz & $49^{\circ} 37^{\prime}$ & $20^{\circ} 42^{\prime}$ & 292 & Wrocław & $51^{\circ} 06^{\prime}$ & $16^{\circ} 53^{\prime}$ & 120 \\
\hline Olsztyn & $53^{\circ} 46^{\prime}$ & $20^{\circ} 25^{\prime}$ & 133 & Zakopane & $49^{\circ} 18^{\prime}$ & $19^{\circ} 57^{\prime}$ & 857 \\
\hline Opole & $50^{\circ} 40^{\prime}$ & $17^{\circ} 58^{\prime}$ & 176 & Zamość & $50^{\circ} 42^{\prime}$ & $23^{\circ} 15^{\prime}$ & 212 \\
\hline Ostrołęka & $53^{\circ} 05^{\prime}$ & $21^{\circ} 34^{\prime}$ & 95 & Zielona Góra & $51^{\circ} 56^{\prime}$ & $15^{\circ} 30^{\prime}$ & 180 \\
\hline
\end{tabular}

Open Access This article is distributed under the terms of the Creative Commons Attribution 4.0 International License (http:// creativecommons.org/licenses/by/4.0/), which permits unrestricted use, distribution, and reproduction in any medium, provided you give appropriate credit to the original author(s) and the source, provide a link to the Creative Commons license, and indicate if changes were made.

\section{References}

Alexander LV, Zhang X, Peterson TC, Caesar J, Gleason B, Klein Tank AMG, Haylock M, Collins D, Trewin B, Rahimzadeh
F, Tagipour A, Rupa Kumar K, Revadekar J, Griffiths G, Vincent L, Stephenson DB, Burn J, Aguilar E, Brunet M, Taylor M, New M, Zhai P, Rusticucci M, Vazquez-Aguirre JL (2006) Global observed changes in daily climate extremes of temperature and precipitation. J Geophys Res Atmos 111: D05109

Alexandersson H (1986) A homogeneity test applied to precipitation data. Int J Climatol 6:661-675

Bryś K, Bryś T (2010) Reconstruction of the 217-year (17912007) Wrocław air temperature and precipitation series. Bull of Geogr (Phys Geogr Series) 3:121-171

Buishand TA (1981) The analysis of homogeneity of long-term rainfall records in the Netherlands. KNMI Scientific Report WR 81-7, De Bilt, The Netherlands. 
Cebulak E, Limanówka D (2007) Days with extreme air temperatures in Poland. In: Piotrowicz K, Twardosz R (eds) Fluctuations of the climate in various spatial and time scales. IGiGP, Uniwersytet Jagielloński, Kraków, pp. 185-194 (in Polish)

Croitoru AE, Piticar A (2012) Changes in daily extreme temperatures in the extra-Carpathians regions of Romania. Int J Climatol 33:19872001

Della-Marta PM, Haylock MR, Luterbacher J, Wanner H (2007) Doubled length of western European summer heat waves since 1880. J Geophys Res 112:D15103

El Kenawy A, Lopez-Moreno JI, Vicente-Serrano SM (2011) Recent trends in daily temperature extremes over northeastern Spain. Nat Haz and Earth System Science 11:2583-2603 www.nathazardsearth-syst-sci.net/11/2583/2011/

Erlat E, Türkeș M (2013) Observed changes and trends in numbers of summer and tropical days, and the 2010 hot summer in Turkey. Int J Climatol 33:1898-1908

Fortuniak K, Kożuchowski K, Żmudzka E (2001) Trendy i okresowość zmian temperatury powietrza $\mathrm{w}$ Polsce $\mathrm{w}$ drugiej połowie $\mathrm{XX}$ wieku. Przegl Geofiz XLVI(4):283-303.

Graczyk D, Kundzewicz ZW (2014) Changes in thermal extremes in Poland. Acta Geophys 62(6):1435-1449

Graczyk D, Kundzewicz ZW (2015) Changes of temperature-related agroclimatic indices in Poland. Theor Appl Climatol. doi:10.1007/ s00704-015-1429-7

Hundecha Y, Bardossy A (2005) Trends in daily precipitation and temperature extremes across Western Germany in the second half of the 20th century. Int J Climatol 25:1189-1202

IPCC (Intergovernmental Panel on Climate Change) (2013) Summary for policymakers. In: Climate change 2013: the physical science basis. Contribution of Working Group I to the Fifth Assessment Report of the Intergovernmental Panel on Climate Change [Stocker T F, Qin D, Plattner G-K, Tignor M, Allen S K, Boschung J, Nauels A, Xia Y, Bex V, Midgley P M (eds.)]. Cambridge University Press, Cambridge, United Kingdom and New York, NY, USA.

Kejna M, Araźny A, Maszewski R, Przybylak R, Uscka-Kowalkowska J, Vizi Z (2009) Daily minimum and maximum air temperature in Poland in the years 1951-2005. Bull of Geogr (Phys Geogr Series) 2:35-56

Klein Tank AM, Konnen GP (2003) Trends in indices of daily temperature and precipitation extremes in Europe, 1946-99. J Clim 16: $3665-3680$

Kossowska-Cezak U, Skrzypczuk J (2011) Hot weather in Warsaw 19472010. Prace Stud Geogr 47:139-146 (in Polish)

Kożuchowski K, Żmudzka E (2001) Ocieplenie w Polsce, skala i rozkład sezonowy zmian temperatury powietrza $\mathrm{w}$ drugiej połowie $\mathrm{XX}$ wieku. Przegl Geofiz XLVI(1-2):81-90
Koźmiński C, Michalska B (2011) Variability in the numbers of cold, cool, warm, hot, and very hot days in Poland in the AprilSeptember period. Przegl Geogr 83(1):91-107 (in Polish)

Kundzewicz ZW, Huang S (2010) Seasonal temperature extremes in Potsdam. Acta Geophys 58(6):1115-1133

Moberg A, Jones PD (2005) Trends in indices for extremes in daily temperature and precipitation in central and western Europe, 1901-99. Int J Climatol 25:1149-1171

Nemec J, Gruber C, Chimani B, Auer I (2013) Trends in extreme temperature indices in Austria based on a new homogenized dataset. Int J Climatol 33:1538-1550

Pettitt AN (1979) A non-parametric approach to the change-point detection. Appl Stat 28:126-135

Radziejewski M, Kundzewicz Z W (2004) Development, use and application of the HYDROSPECT data analysis system for the detection of changes in hydrological time-series for use in WCP-Water and National Hydrological Services, WCASP65, Hydrospect, Version 2.0. User's manual, WMO, Geneva, Switzerland.

Shevchenko O, Lee H, Snizhko S, Mayer H (2014) Long-term analysis of heat waves in Ukraine. Int J Climatol 34:1642-1650

Stanisławska K, Kundzewicz ZW, Krawiec K (2013) Hindcasting global temperature by evolutionary computation. Acta Geophys 61(3): $732-751$

Twardosz R, Kossowska-Cezak U (2013) Exceptionally hot summers in Central and Eastern Europe (1951-2010). Theor Appl Climatol 112(3):617-628

Twardosz R, Kossowska-Cezak U (2015) Exceptionally hot and cold summers in Europe (1951-2010). Acta Geophys 63(1):275-300

Vose RS, Easterling DR, Gleason B (2005) Maximum and minimum temperature trends for the globe: an update through 2004. Geophys Res Lett 32:L23822.

Von Neumann J (1941) Distribution of the ratio of the mean square successive difference to the variance. Ann Math Stat 13:367-395

Wibig J (2012) Has the frequency or intensity of hot weather events changed in Poland since 1950? Adv Sci Res 8:87-91

Wijingaard JB, Klein Tank AMG, Können GP (2003) Homogeneity of 20th century European daily temperature and precipitation series. Int J Climatol 23:679-692

Xoplaki E, Gonzalez-Rouco JF, Luterbacher J, Wanner H (2003) Mediterranean summer air temperature variability and its connection to the large-scale atmospheric circulation and SSTs. Clim Dyn 20:723-839

Yan Z, Jones PD, Davies TD, Moberg A, Bergström H, Camuffo D, Cocheo C, Maugeri M, Demarée GR, Verhoeve T, Thoen $\mathrm{E}$, Barriendos $\mathrm{M}$, Rodríguez $\mathrm{R}$, Martín-Vide J, Yang $\mathrm{C}$ (2002) Trends of extreme temperatures in Europe and China based on daily observations. Clim Chang 53:355-392 